\title{
SOKSZÍNŰ PEDAGÓGIA
}

A tanulmánykötet remek összeállításban szerkesztett kiadvány. Az első fejezet a mentális egészség és a társas kapcsolatok iskolai, pedagógiai vonatkozásaival foglalkozik. A következő rész a multikulturális nevelés jellemzőit, feltételeit írja le. A harmadik az inkluzív gyakorlatokat mutatja be, míg a negyedik fejezetben két tanulmány a vallások gyermekképére tér ki.

Az első fejezet kezdő tanulmánya behatóan foglalkozik a mentális egészséggel. F. Lassú Zsuzsa és Várszegi Petra szerzők sorra veszik azokat az erőforrásokat, amelyekre a mentálisan sérült szülők gyermekei támaszkodhatnak annak érdekében, hogy ők maguk mentálisan egészségesek maradjanak. Egy 2010-es tanulmányra hivatkozással a szerzőpáros arra hívja fel a figyelmet, hogy a tanulási zavarokkal küzdő gyermekek közel kétharmadánál kialakul valamilyen mentális, egészségi zavar. Természetesen a pedagógus nem mentálhigiénés szakember, nem pszichológus, így adódhatnak helyzetek, amikor jelzőként kell müködnie, és a gyermeket szakemberhez irányítania.

Az atipikus fejlődésről szól Gyarmathy Éva írása, amely a diszlexia, diszgráfia, diszpraxia, diszkalkulia, figyelemzavar és a hiperaktivitás háttérben álló idegrendszeri folyamatokkal foglalkozik. A harmadik tanulmány Lénárt András tollából született, aki az inklúziómérésnek a lehetőségét fejti ki.

A következő Füzesné Illés Zsuzsanna írása, aki olyan kutatást mutat be, amelynek témája az egyén teljesítménymotivációja. A tanulmány által bemutatott kutatás arra hívja fel a figyelmet, hogy a társakhoz viszonyító teljesítménymotiváció inkább negatívan befolyásolja a tanulmányi előmenetelt. Azok, akik inkább az objektív(ebb) eredményekhez viszonyították saját céljaikat, nemcsak eredményesebbnek bizonyultak, hanem több társas kapcsolattal is rendelkeztek az osztályon belül.

A pedagógusnők mentálhigiénés állapotával Borbáth Katalin foglalkozott, aki arra a következtetésre jutott, hogy a mentálhigiénés sérülékenység bizonyos személyiségjegyeken múlik. Ehhez kapcsolható az a kutatás, mely Ádám Szilvia nevéhez kötődik. Ebben a tekintetben a legfőbb stresszorok kerülnek lejegyzésre: a tanulók csökkenő érdeklődése, fejlődésük elmaradása, az objektív feltételek és a támogató személyzet hiánya. Az eredmények közlése alapján a fizikai aktivitás védő tényezőnek bizonyult, ugyanakkor a problémaközpontú megoldási stratégiák inkább kockázati tényezőként jelentek meg.

A kötet második egységének tanulmányai a multikulturális nevelés témája köré szerveződnek. Az első tisztázni igyekszik az inter- és a multikulturális nevelés fogalmát, a köztük levő különbséget. A Gőbőlős Rebeka Anna-Endrődy 
Orsolya szerzőpáros rámutat arra, hogy lényegében mindkét fogalom kölcsönös elfogadásra nevel. Szerintük az egyetlen különbség, hogy a multikulturális társadalomban az egyes alcsoportok kevésbé vannak kapcsolatban egymással, míg az interkulturális társadalmakban szorosabb a kapcsolódás. Megállapítja azt is, hogy Magyarországon a multikulturális nevelésnek nincs kialakult formája, folyamatosan fejlödik. Azonban szerencsés helyzetben vannak a német nemzetiségi köznevelési intézmények, mert nagyon népszerűek. Márkus Éva úgy véli, hogy az integráció, a német és a más nemzetiségü gyermekek együttnevelése lényegében nem okoz nehézségeket. Müller Márta tanulmánya a német nemzetiségi óvodapedagógusi és tanítói képzéssel foglalkozik. Úgy véli, hogy viszonylag kedvező a helyzet, hiszen a nemzetiségi pedagógusképzésbe jelentkezők 75 százaléka a német képzést választja. Ugyanakkor problémát jelent, hogy nem mindig sikerül betölteni az elöírt minimumlétszámot, így a szerző javasolja annak csökkentését.

A kétnyelvü tanulók integrálásával kapcsolatban Kovács Judit és Trentinné Benkő Éva, egy konkrét intézmény eredményességét vizsgálták. A Magyarországon élő második generációs vietnámiak befogadásáról Kovács Luca Sára kutatási eredményei a kettős kulturális közegre utalnak. A magyar nyelv ismerete magas szintü, az iskolai tanulás nem okoz gondot számukra. Identitásuk kettős, jobban szeretik magukat „vietnámi magyarként” meghatározni, mint csak „magyarként” vagy csak „,vietnámiként”. Az afrikai-magyar gyermekek helyzetét Komolafe Cinderella fejti ki; ök kevésbé élnek kedvező helyzetben, mint akár a német, akár a vietnámi magyar gyermekek. Több diszkriminációval, rasszista megnyilvánulással találkoznak. Ugyanakkor a kétnyelvüség és a kettős kultúra számukra is gyakran jelenik meg előnyként a tanulás során.

A fejezet záró tanulmányai, Szabóné Kármán Judit és Hortoványi Judit írásai; mindkettő a hazai roma gyermekek és családok helyzetével foglalkozik. Kiemelik az iskolázottsági mutatókat majd az egységes szocializáció hiányáról is olvashatunk. A tanulmányok ebben a tekintetben egyértelmüen utalnak arra, hogy a hátrányokat csak olyan intézmények tudják korrigálni, amelyek ismerik a romákra jellemző szocializációs sajátosságokat.

A kötetben nyolc tanulmány foglalkozik az inklúziósegítő, jó gyakorlatok bemutatásával. Perlusz Andrea szerint a befogadó attitűd csak a pedagógusok magas színvonalon való együttmúködése révén jöhet létre, ha közös a problémakezelés, és az értékek képviseletében konszenzus uralkodik. Kollár János hasonló gondolatmenetben a befogadó társadalom és befogadó iskolák szerepéröl ír, benne a fogyatékossággal élő emberek kirekesztettség elleni küzdelmét boncolgatja.

Angol, spanyol és japán példák kerülnek bemutatásra az interkulturális sokszínűség gyakorlatából. Endrődy bemutatja, hogy miért fontos, és hogyan készüljünk fel a hazai és többségi kultúrától eltérő, hazánkba érkező gyermek fogadására.

A Kincses játékok címet viselő tanulmányhoz, Ozsváth-Anga Erikának az Én Kincsesem képességfejlesztő játékgyüjteménye adta az alapot. Berzsenyi Emese a 
fogyatékosság társadalmi összefüggéseit vizsgálta, valamint arra fókuszált, hogy a problémát a 21. században miként érthetjük meg.

A japánból származó papírszínházról keveset tudunk. Az egyébként „audiovizuális ingeregyüttesre építő módszer" magyar nyelvű szakirodalma fejlesztésre szorul, és ezt igyekszik pótolni Nagy-Jónás Izabella és Svraka Bernadett közös írása.

Elekes Györgyi kutatása a pedagógus személyével foglalkozik. A tanulmányban bemutatott kutatás diplomás romák életútját vizsgálta. Az eredmények azt mutatják, hogy a tanulmányi elömenetel nem véletlenszerü; abban nagyon fontos szerepe volt az általános és középiskolának. Emellett fontos szerepe volt az olyan makrotársadalmi tényezőknek, mint például a tanulmányi ösztöndíj.

A kötetet záró két tanulmány a zsidóság, a kereszténység és az iszlám vallás gyermekképével foglalkozik. Berzsenyi Emese írása létfilozófiai kérdésként tekintette át az ábrahámi vallások emberfelfogását, mely szerint a gyermek a szülők életének továbbvivője, Isten ajándéka. Endrődy Orsolya pedig a távol-keleti kultúrák gyermekképét elemzi. Ezekben fontos fogalom a „gyermekiesség”, azaz a gyermekkor játékos megélése. A gyermek szabadsága mellett is tiszteli a szüleit, és szereti a természetet, azzal harmóniában él. A gyermek anyai gondoskodással körülvéve, tiszteletteljes magatartásra törekszik. Ha egy pedagógus ilyen kultúrából érkező gyermeket nevel, akkor fontos ezeket az elveket elfogadnia és támogatnia.

A kiadvány címe sejteti, hogy a tanulmányokban sokszínủ, számos témát érintő írásokkal találkozhatunk, és ez be is bizonyosodik. A bemutatott elemzések, gyakorlatok és módszerek mind a pedagógusok, mind pedig a pedagógusjelöltek számára nagy haszonnal forgathatók.

(Endrödy Orsolya - Svraka Bernadett - F. Lassú Zsuzsa szerkesztök: Sokszinü pedagógia. Inkluziv és multikulturális szemléletmód a pedagógiában. Budapest: ELTE Eötvös Kiadó, 2020)

Jaskóné dr. Gácsi Mária

$\mathrm{PhD}$, egyetemi docens Miskolci Egyetem Bölcsészettudományi Kar Tanárképző Intézet 